\title{
The practice of self-medication for treatment of illnesses for under-five children by mothers in Ibadan, Nigeria
}

Kabiru K. Salami* and Olubukola J. Adesanwo

*Correspondence: kabsalami@yahoo.co.uk

\author{
CrossMark
}

\& Click for updates

Department of Sociology, University of Ibadan, Nigeria.

\begin{abstract}
The required ability of individuals to practise 'responsible self-medication' on minor ailments without medical practitioners' attention is demonstrably lacking among mothers of under-five children in Nigeria. There are few studies on mothers' practice of responsible self-medication in Nigeria. Thus, this study was carried out to investigate the practice of self-medication among 226 mothers of under-five children in Ibadan, Nigeria. Findings revealed that 53.4\% mothers of under-five whose children fell sick two weeks before the survey applied self-medication as first action; $81.4 \%$ disclosed that they ever administered nonprescribed drugs for their children, $47.3 \%$ reportedly applied self-medication based on competence, while $19 \%$ were encouraged by family members to use non-prescribed drugs. Healthcare practitioners should involve household members in focused awareness on self-medication and its negative implications in order to encourage them to serve as change agents against the practice by mothers.
\end{abstract}

Keywords: Management of childhood illnesses, patent medicine vendor, self-medication, under-five children, Nigeria

\section{Introduction}

Self-medication is undeniably a major global practice which influences individuals' behaviour while taking decision concerning their health. The universal practice of self-medication and irrational use of drugs as a major public health concern [1] among human population [2] drove the World Health Organization to recognize the phenomenon as a crucial part of public health care system [3] referred to as 'responsible selfmedication' [4]. The concept of self-medication involves the use of medicine with curative intent but without professional advice [5-6]. It also depicts the act of obtaining and consuming drugs without the advice of a medical practitioner either for diagnosis, prescription or treatment of disease and illness [7]. Conversely, self-medication is a way to encourage individuals to look after minor ailments with simple and effective antidotes that have been adopted globally $[8,9]$. Hence, it is an integral part of self-care which can be considered as primary public health resource in the health care system. It includes self-medication, non-drug self-treatment, social support in illness, and first aid in everyday life [3].

Responsible self-medication, especially where treatment of family members such as children and elderly are involved, is tailored around the advice of pharmacists for any medicinal products that are intended for self-medication $[3,4]$. This provides possibilities for some potential benefits in relation to healthrelated decision-making process, if applied correctly. Afolabi [10] observed how studies in the United States and Britain, for instance, had indicated that about $50-75 \%$ of treatment was through the practice of self-medication. Consumers' depth of knowledge on accurate recognition of symptoms, personal medical history and contraindications among others are variables needed for self-medication. However, inappropriate use of self-medication can increase 'drug-induced disease', death and waste of public funds, bacterial infection, hypersensitivity and drug withdrawal symptoms $[3,11,12]$.

The growing trends of improper use of self-medication have been attributed to the wide spread availability of over-thecounter (OTC) drugs [13], urge of self-care, lack of functional health care services, poverty, ignorance, extensive advertisement of drugs, high fees at health facilities, availability of drugs in places other than drug shops and inadequate family support [14-16]. Misuse and abuse of prescribed drugs, errors of medication, combination of orthodox and herbal medicine, and use of non-prescribed drugs by mothers or caregivers may hamper children's health [17-19]. In order to attenuate the trends, the WHO asserts the dangers of antibiotics self-medication and reaf- 
Salami et al. Research Journal of Drug Abuse 2015,

http://www.hoajonline.com/journals/pdf/2057-3111-2-2.pdf

doi: $10.7243 / 2057-3111-2-2$

firmed that it has contributed to antibiotic resistance [20-22].

In a study of home management of childhood diseases, it was reported that about $48 \%$ of self-medication occurred among infants in Nigeria [4]. Abasiubong et al., [23] reported the practice of self-medication in Nigeria and specifically examine its potential risk and hazard among pregnant women in Uyo Nigeria. The health of under-five children is important not only to the parents but also to the entire members of the child's household [24]. The frequently treated illness with self-medication among infants in the country includes constipation, fever, cough and abdominal pain [25]. The increasing rate of pharmacy shops globally [26-28] enhances consumers' accessibility to medicine thereby creating options for its misuse due to self-medication [1] not only by mothers of under-five children but also among group of health workers and nursing students in Nigeria [29], practising physicians $[30,31]$ and undergraduate medical students in India [1]. Mothers of under-five years children have been found playing numerous and vital roles in curative drug use and can be enticed to buy prescribed and non-prescribed drugs from different sources [32]. Despite the prevalence of this practice, there exist dearth of literature on the scope of self-medication phenomenon for under-five children in $\mathrm{Ni}$ geria. Hence, the practice of self-medication for treatment of illnesses for under-five children by mothers is what this study documents by examining the prevalence of illness among children of under-five years, the practice of and the factors that influence self-medication among mothers of under-five children, the perception of self-medication and attitude of the mothers towards self-medication in Nigeria.

\section{Methods \\ Study area}

This study was conducted in Ibadan, the capital of Oyo State, in South-Western Nigeria. Ibadan is made up of 11 local government areas (LGAs) with 2,550,593 population [33]. A more recent data from the National population commission (NPC) office in Ibadan put an estimated population of the city at 3,232,016 in 2014. Out of 11 LGAs in Ibadan, five are located within the metropolis while the remaining six LGAs are located at the outskirts of the city. Two LGAs in Ibadan metropolis- Ibadan North and Ibadan South-East were chosen for the study. Ibadan North LGA has the highest number of health facilities in the ancient city; the LGA has ten public primary health facilities, one public secondary facility and one tertiary health facility. There are also 115 registered private hospitals, clinics and maternity centres in the LGA (Buffett Centre, year n/a). Ibadan South-East LGA was chosen due to the fact that there are few major health centres in the area.

\section{Field procedures}

The study adopted multi-stage sampling techniques. Out of twelve political wards each in Ibadan North and Ibadan South-East LGAs [34], six political wards were selected from each of the two LGAs through systematic sampling method. Three wards were later selected from the six wards of each area. The political ward that fell as number two in Ibadan North and the ward that fell as number two in Ibadan South-East were selected as study areas. In all, two political wards were selected from the two LGAs which were later segregated into clusters to avoid double interviews. One hundred and twenty-five copies of questionnaire were administered in each of the political wards totaling two hundred and fifty in all. However, out of the 250 questionnaires administered, only 226 (90.4\%) were returned and included in the analysis.

Two respondent inclusion criteria were used: being a mother who has an under-five child and willingness to participate in the study. Any mother who did not meet the criteria was not interviewed. The consent of potential respondents was sought and those who did not consent to participating in the study were politely exempted. Completed copies of the questionnaire were edited on a daily basis and were kept in a safe place. Data were coded and analyzed using the Statistical Package for Social Science (SPSS) software version 15. Variables and categories were generated in order to measure the relationship between variables of interest and data were analyzed using simple descriptive statistics. Responses to statement questions on the perceptions of mothers towards self-medication and their attitudes were rated as $\mathrm{SA}=$ Strongly Agreed, $\mathrm{A}=$ Agreed, In=Indifferent, $D=$ Disagreed and $S D=$ Strongly Disagreed. These responses were scored as $S A=5, A=4, \ln =3, D=2$ and $S D=1$ giving rise to $5+4+3+2+1=15$ with mean score of 3 . Hence a mean score above 3 points indicates that respondents agreed with the statement while a mean score below 3 shows a disagreement with the statement. The Remarks revealed the overall opinion of the respondents as either agreed or disagreed with their responses. This, by implication, means that the mean score of a statement that shows 3 and above is remarked as 'agreed' with the statement while conversely, the mean score below 3 is remarked as 'disagreed' with the statement.

\section{Results}

Socio-demographic characteristics of the respondents In all, the respondents were 226 mothers of under-five children with a mean age of 30 (range 18-46 years). The monthly income of the mothers was found to be two thousand Naira $(\$ 12.50)$ as minimum and five hundred thousand Naira $(\$ 3,125)$ as maximum with an overall average income of twenty-eight thousand Naira (\$175). Table 1 shows that majority (62.4\%) of the respondents were Christian while $35 \%$ were Muslims. Most (43.8\%) of the respondents had secondary school education as highest educational level attained. Table 1 also shows that respondents with postsecondary educational status were $40.6 \%$ altogether. Only $11.1 \%$ of the respondents obtained primary school leaving certificate only. A large majority (94.7\%) of the respondents reportedly married as the only wife to their husband, while others were reportedly married 
Salami et al. Research Journal of Drug Abuse 2015,

Table 1. Sociodemographic structure of the respondents.

\begin{tabular}{lll}
\hline Sociodemographic & Frequency & Percent \\
\hline Age (18-46) & 226 & 100 \\
\hline Religion & & \\
\hline Christianity & 141 & 62.4 \\
Islam & 79 & 35.0 \\
Indigenous & 1 & 0.4 \\
No response & 5 & 2.2 \\
Total & 226 & -- \\
\hline Educational status & & \\
\hline Primary school & 25 & 11.1 \\
Secondary school & 99 & 43.8 \\
National Certificate in Education (NCE) & 43 & 19.0 \\
Ordinary National Diploma (OND) & 17 & 7.5 \\
Higher National Diploma (HND) & 8 & 3.5 \\
B.Sc & 14 & 6.2 \\
M.Ed & 7 & 3.1 \\
Ph.D & 3 & 1.3 \\
Others: Arabic, diploma & 7 & 3.1 \\
No response & 3 & 1.3 \\
Total & 226 & -- \\
\hline Number of wives to a husband & &
\end{tabular}

\begin{tabular}{lll}
\hline Number of wives to a husband & & \\
\hline 1 wife & 214 & 94.7 \\
2 wives to a man & 6 & 2.7 \\
3 wives to a man & 5 & 2.2 \\
4 wives to a man & 1 & 0.4 \\
Total & 226 & -- \\
\hline Position of respondent among co-wives to husband \\
\hline $1^{\text {st }}$ position & 197 & 87.2 \\
$2^{\text {nd }}$ position & 3 & 1.3 \\
$3^{\text {rd }}$ position & 6 & 2.7 \\
No response & 20 & 8.8 \\
Total & 226 & -- \\
\hline
\end{tabular}

\begin{tabular}{lll}
\hline Parity level & 226 & -- \\
\hline One child & 60 & 26.5 \\
Two children & 66 & 29.2 \\
Three children & 58 & 25.7 \\
Four children & 30 & 13.3 \\
Five children & 8 & 3.5 \\
Six children & 3 & 1.3 \\
Eight children & 1 & 0.4 \\
Total & 226 & -- \\
\hline Age of children & & \\
\hline 0-11 months & 54 & 23.8 \\
12-23 months & 49 & 21.7 \\
24-35 months & 41 & 18.1 \\
$36-47$ months & 59 & 26.1 \\
$48-59$ months & 23 & 10.2 \\
Total & 226 & -- \\
\hline
\end{tabular}

to a husband with two to four wives. The parity level of the respondents ranged between one (26.5\%) and eight children (0.4\%). Respondents with two children were $29.2 \%$. Table 1 shows that slightly above half (54.4\%) of the mothers had children whose age ranged from 3 to five years while $23.8 \%$ mothers had children who were within one year old. In all, $53.4 \%$ mothers reportedly practised self-medication as an option to treat their children's illnesses in the previous two weeks before the survey.

\section{Prevalence of childhood illnesses}

Almost half (49.1\%) of the mothers indicated malaria fever as the most common childhood illness in their area of residence followed by cold (22.6\%) while $9.3 \%$ indicated measles also as common. The scenario changed when the question also changed from general prevalence in the community to personal experience of illness. For instance, in the experience of mothers about their children as at time of the study, malaria (31.4\%) was reportedly more common than measles (17.3\%) just like the prevalence rate in the community though not as high as the community prevalence rate. However, cold, catarrh, measles and cough were reportedly higher at individual experience level than the community experience, as presented in Figure 1.

\section{Treatment behaviour of mothers}

A large majority $(81.4 \%)$ of the respondents reportedly administered non-prescribed drugs to their children. Slightly above a quarter (26.6\%) of the respondents who administered non-prescribed drugs $(n=184)$ reportedly used it to treat malaria. About half (48.9\%) of them obtained their drugs from patent medicine vendors (PMVs) around their homes or from pharmacy stores $(n=42.9 \%)$ and other sources as shown in Table 2. The main factors that prompted their choices were level of competence, availability and cost. Respondents' major decisions were influenced by advertisement (38.6\%) and family members (19.0\%) among others as shown in Table 2.

\section{Mothers' perception on self-medication}

Table 3 presents respondents' perception about self-medication. Analysis of responses to statement questions raised revealed

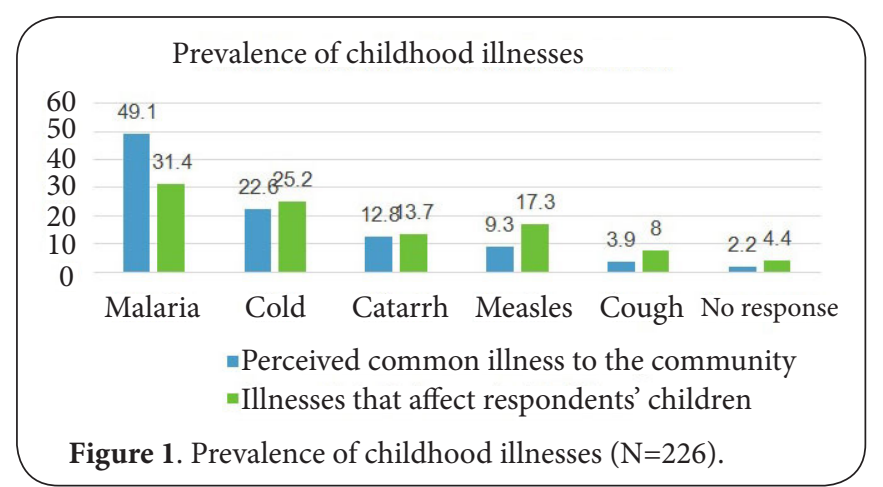


Salami et al. Research Journal of Drug Abuse 2015,

Table 2. Treatment behaviour of mothers.

\begin{tabular}{lll}
\hline $\begin{array}{l}\text { Administration of non-prescribed } \\
\text { drugs (N=226) }\end{array}$ & Frequency & Percentage \\
\hline Yes & 184 & 81.4 \\
No & 38 & 16.8 \\
No response & 4 & 1.8 \\
\hline Types of sickness for administration of & Frequency & Percentage \\
non-prescribed drugs (N=184) & & \\
\hline Malaria & 49 & 26.6 \\
Body pain & 35 & 19.0 \\
Cold & 41 & 18.1 \\
Diarrhea & 32 & 17.4 \\
Catarrh & 27 & 14.7 \\
\hline Preferred source of non-prescribed & Frequency & Percentage \\
drugs (N=184) & & \\
\hline Chemist stores & 90 & 48.9 \\
Pharmacy stores & 79 & 42.9 \\
Medicine hawkers & 6 & 3.3 \\
Others (drugs already had at home) & 7 & 3.8 \\
No response & 2 & 1.1 \\
\hline Reasons for the preferred source (N=184) & Frequency & Percentage \\
\hline Competence & 107 & 47.3 \\
Availability & 64 & 28.3 \\
Cost & 25 & 11.1 \\
Proximity & 19 & 8.4 \\
No response & 11 & 4.9 \\
\hline Sources of influence on mothers who & Frequency & Percentage \\
administered non-prescribed drugs & & \\
(N=184) & & \\
\hline Advertisement & 71 & 38.6 \\
$\begin{array}{l}\text { Family members } \\
\text { Friends }\end{array}$ & 35 & 19.0 \\
No response & 19 & 10.3 \\
\hline
\end{tabular}

that respondents accepted (aggregate score of 3.1) the use of "leftover drugs for future sickness"; the mean score of 3.3 depicts that mothers aggregately used "old prescription" to get new drugs; and they abandoned "prescribed drugs once traces of recovery is noticeable" in the child. Also shown in Table 3 is that respondents generally agreed (3.8) that "everybody practised self-medication".

Table 3 also depicts that mothers were not opposed to the use of herbal medicine by pregnant women and children under the age of five. It also indicates that mothers care less about the source of drugs since "point of getting drug would not affect its purpose".

Mothers' attitudes towards the practice of self-medication Mothers' attitudes indicated a high level of the practice of self-medication and revealed that mothers prefer injection to drugs for treatment of illness at mean score of 3.0. However, mothers were opposed (1.9) to the preference of syrup drugs over coated drugs. The mean score of 3.1 in this study indicates that mothers believe that drugs prescribed by doctors do not always work for the purpose of the sickness. Hence, the respondents agreed (3.1) that mothers gave anything good to children irrespective of doctor's advice, and at the same time agreed (3.3) that it was better to give right medicine to children than to visit doctors every time. However, the respondents agreed (3.2) that all drugs would not work for all situations. Table 4 also shows that mothers opined (3.2) that not every prescribed drug should be given to children due to serious adverse effects they could have. Respondents were opposed (2.0) to the use of a combination of orthodox and herbal drugs for treatment, as shown in Table 4.

\section{Discussion}

This study has revealed that childrearing processes involve

Table 3. Mothers' perception of the practice of self-medication $(\mathrm{N}=226)$.

\begin{tabular}{|c|c|c|c|c|c|c|c|}
\hline Statements of mothers' perception & SA & $\mathbf{A}$ & In & $\mathrm{D}$ & SD & Mean score & No response \\
\hline $\begin{array}{l}\text { When non-prescribed drugs failed to work, doctors' } \\
\text { advice is not important. }\end{array}$ & $17(7.5)$ & $95(42.0)$ & $6(2.7)$ & $59(26.1)$ & $41(18.1)$ & 2.9 & $8(3.5)$ \\
\hline Mothers consulted doctors for all drugs prescription. & $24(10.6)$ & $78(34.5)$ & $6(2.7)$ & $58(25.7)$ & $54(23.9)$ & 2.8 & $6(2.7)$ \\
\hline $\begin{array}{l}\text { Mothers used previous prescribed drugs when } \\
\text { similar symptom reappeared. }\end{array}$ & $34(15.0)$ & $131(58.0)$ & $10(4.4)$ & $21(9.3)$ & $22(9.7)$ & 3.6 & $8(3.5)$ \\
\hline Mothers used leftover drugs for future sickness. & $37(16.4)$ & $84(37.2)$ & $13(5.8)$ & $41(18.1)$ & $44(19.5)$ & 3.1 & $7(3.1)$ \\
\hline Mothers used old prescription to get new drugs. & $43(19.0)$ & $88(38.9)$ & $16(7.1)$ & $41(18.1)$ & $32(14.2)$ & 3.3 & $6(2.7)$ \\
\hline $\begin{array}{l}\text { Mothers abandon prescribed drugs once a sign of } \\
\text { recovery is shown. }\end{array}$ & $31(13.7)$ & $89(39.4)$ & $13(5.8)$ & $67(29.6)$ & $25(11.1)$ & 3.2 & $1(0.4)$ \\
\hline $\begin{array}{l}\text { Mothers collected, prepared and consumed herbal } \\
\text { medicine. }\end{array}$ & $36(15.9)$ & $86(38.1)$ & $26(11.5)$ & $36(15.9)$ & $39(17.3)$ & 3.1 & $3(1.3)$ \\
\hline $\begin{array}{l}\text { Consumption of herbal medicine by pregnant } \\
\text { women and children under-five is bad. }\end{array}$ & $22(9.7)$ & $41(18.1)$ & $16(7.1)$ & $98(43.4)$ & $45(19.9)$ & 2.5 & $4(1.8)$ \\
\hline Everyone indulges in self-medication. & $48(21.2)$ & $95(42.0)$ & $30(13.3)$ & $29(12.8)$ & $13(5.8)$ & 3.8 & $11(4.9)$ \\
\hline Point of getting drug would not affect its purpose. & $15(6.6)$ & $39(17.3)$ & $30(13.3)$ & $81(35.8)$ & $50(22.1)$ & 2.5 & $11(4.9)$ \\
\hline
\end{tabular}

SA: Strongly Agreed, A: Agreed, In: Indifferent, D: Disagreed and SD: Strongly Disagreed 
Salami et al. Research Journal of Drug Abuse 2015,

http://www.hoajonline.com/journals/pdf/2057-3111-2-2.pdf

Table 4. Mothers' attitude towards the practice of self-medication $(\mathrm{N}=226)$.

\begin{tabular}{|c|c|c|c|c|c|c|c|}
\hline Statement on mothers' attitude on self-medication & SA & A & In & $\mathrm{D}$ & SD & Mean Score & No response \\
\hline Mothers preferred injection to drugs during treatment. & $32(14.2)$ & $57(25.2)$ & $39(17.3)$ & $67(29.6)$ & 27 (11.9) & 3.0 & $4(4.8)$ \\
\hline Drugs prescribed by doctor do not always work. & $20(8.8)$ & $90(39.8)$ & $24(10.6)$ & $67(29.6)$ & $19(8.4)$ & 3.1 & $6(2.7)$ \\
\hline Mothers preferred syrup drugs to coated drugs. & $8(3.5)$ & $21(9.3)$ & $13(5.8)$ & $88(38.9)$ & $93(41.2)$ & 1.9 & $3(1.9)$ \\
\hline $\begin{array}{l}\text { Mothers give anything good to children irrespective } \\
\text { of doctor's advice. }\end{array}$ & $20(8.8)$ & $106(46.9)$ & $10(4.4)$ & $46(20.4)$ & $41(18.1)$ & 3.1 & $3(1.3)$ \\
\hline $\begin{array}{l}\text { Mothers giving right medicine to children is better } \\
\text { than seeing the doctor every time. }\end{array}$ & $26(11.5)$ & $121(53.5)$ & $7(3.1)$ & $42(18.6)$ & $27(11.9)$ & 3.3 & $3(1.3)$ \\
\hline All drugs would not work for all situations. & $25(11.1)$ & $107(47.3)$ & $17(7.5)$ & 37 (16.4) & $36(15.9)$ & 3.2 & $4(1.7)$ \\
\hline $\begin{array}{l}\text { Not every prescribed drug should be given to } \\
\text { children due to serious adverse effects. }\end{array}$ & $18(8.0)$ & $82(36.3)$ & $19(8.4)$ & $69(30.5)$ & $35(15.5)$ & 3.2 & $3(1.3)$ \\
\hline $\begin{array}{l}\text { Doctors could make mistake in the course of drugs } \\
\text { prescription. }\end{array}$ & $37(16.4)$ & $102(45.1)$ & $47(20.8)$ & 27 (11.9) & $5(2.2)$ & 3.6 & $8(3.5)$ \\
\hline $\begin{array}{l}\text { Mothers do not adhere to drug instruction on its } \\
\text { leaflet. }\end{array}$ & $37(16.4)$ & $102(45.1)$ & $47(20.8)$ & 27 (11.9) & $5(2.2)$ & 3.6 & $8(3.5)$ \\
\hline
\end{tabular}

SA: Strongly Agreed; A: Agreed; In:Indifferent; D: Disagreed and SD: Strongly Disagreed

contentious practices concerning care for childhood ailment and diseases. Self-medication has been documented a common practice to respond to childhood ailment among mothers of under-five children. The educational attainment of respondents in this study is not equitably high, as at least three of every five women interviewed did not have more than secondary education. Whereas education was described as a domain part of quality of life [35], it is also significantly associated with household wealth status $[36,37]$. Hence, it may invariably affect mothers' knowledge about responsible self-medication [4].

Self-medication is rampant (53.4\%) among the studied population. This result conforms to other previous studies $[7,14,38]$ that have also documented high rate of the practice of self-medication among urban children in Nigeria. Seven out of ten mothers in this study failed to consult doctor as first action when their children felt ill, due to reasons such as proximity to medicine stores, availability of non-prescribed drugs, competence or seeing patent medicine vendors (PMV) as major advisers on their illness, low cost or financial constraint and extensive drug advertisement as this study and other studies have confirmed [4,14-16,39-41].

This study shows that as much as advertisement serves good purpose in promotion of best drug use practice, it could also give impetus to self-medication. For instance, respondents in this study indicated that advertisement, among other factors, (38.6\%) highly motivated them for self-medication practice. Burak and Damico [42] observed that increased advertising of pharmaceuticals poses a larger threat of self-medication to the population in general. Advertisement that delves on drugs should be conscious of purposeful instruction that discourages self-medication practice. More importantly, self-medication is being substituted for appropriate medical consultation. This study shows that people use previously prescribed drugs when similar symptom reappears, and use old prescription to get new drugs. This raises concerns of incorrect self-diagnosis, drug interaction, and use of drugs for purposes other than originally prescribed [42]. Such practices could aggravate ill health conditions and more importantly have high tendencies for hampering home management of illness practice by mothers before reporting to hospitals [43-46]. One factor that cannot be underestimated is the influence of significant others. This study documents the existence of co-wives in about $5 \%$ of the respondents. Where there are more than one woman, the role of other women could be important in decisions on self-medication.

Advertisement of drugs should include discouragement of practice of self-medication. This should be enhanced by serious policy attention over drugs' advertisement. Focused health education should consider mothers as well as household members and PMVs for enlightenment on self-medication in Nigeria.

\section{Competing interests}

The authors declare that they have no competing interests.

Authors' contributions

\begin{tabular}{|l|c|c|}
\hline Authors' contributions & KKS & OJA \\
\hline Research concept and design & $\checkmark$ & $\checkmark$ \\
\hline Collection and/or assembly of data & $\checkmark$ & $\checkmark$ \\
\hline Data analysis and interpretation & $\checkmark$ & -- \\
\hline Writing the article & $\checkmark$ & -- \\
\hline Critical revision of the article & $\checkmark$ & $\checkmark$ \\
\hline Final approval of article & $\checkmark$ & $\checkmark$ \\
\hline Statistical analysis & $\checkmark$ & -- \\
\hline
\end{tabular}

Acknowledgement

The authors are grateful to the participants who voluntarily partake in this study. 
Salami et al. Research Journal of Drug Abuse 2015,

http://www.hoajonline.com/journals/pdf/2057-3111-2-2.pdf

doi: $10.7243 / 2057-3111-2-2$

Publication history

Editor: Sawsan Abuhamdah, University of Jordan, Jordan.

Received: 08-Aug-2015 Final Revised: 21-Sep-2015

Accepted: 02-Oct-2015 Published: 13-Oct-2015

\section{References}

1. Kumar N, Kanchan T, Unnikrishnan B, Rekha T, Mithra P, Kulkarni V, Papanna MK, Holla R and Uppal S. Perceptions and practices of selfmedication among medical students in coastal South India. PLoS One. 2013; 8:e72247. | Article | PubMed Abstract | PubMed Full Text

2. Balamurugan $E$ and Ganesh K. Prevalence and pattern of self-medication use in coastal regions of South India. BJMP. 2011; 4:428. I Article

3. WHO. Guidelines for the regulatory assessment of medicinal products for use in Self-medication. 2000. I Pdf

4. Jain S, Malvi R and Purviya JK. Concept of Self Medication: A Review. International Journal of Pharmaceutical and Biological Archives. 2011 2:831-836. | Article

5. Covington TR. Non-prescription medications and self-care. Nonprescription Drug Therapy: Issues and Opportunities. Am J Pharm Educ. 2006; 70:137. I Article

6. Atray $M$ and Kumar R. Self-medication pattern and its comparison amongst medical and non-medical college students of Udaipur, India. Int'l Jour. Res Rev. 2013; 5. I Article

7. Oshikoya KA, Njokanma OF, Bello JA and Ayorinde EO. Family selfmedication for children in an urban area of Nigeria. Paed. and Perinatal Drug Therapy. 2007; 8:124-130.

8. Awad A, Eltayeb I, Matowe L and Thalib L. Self-medication with antibiotics and antimalarials in the community of Khartoum State, Sudan. J Pharm Pharm Sci. 2005; 8:326-31. | Article | PubMed

9. Major C, Vincze Z, Mesko A, Balogh J, Zelko R and Nemeth E. [Medicating outside the consulting room]. Orv Hetil. 2007; 148:291-8. I Article I PubMed

10. Afolabi AO. Self Medication, Drug Dependency and Self-Managed Health Care - A Review. Public Health - Social and Behavioral Health, Prof. Jay Maddock (Ed.). 2012. I Book

11. Dayani G, Luciana MG, Graziela MA and Silvana CT. Responsible selfmedication: review of the process of pharmaceutical attendance. Brazilian J Pharm Sci. 2009; 45:625-633. I Article

12. Schmid B, Bernal R and Silva NN. Self-medication in low-income adults in Southeastern Brazil. Rev Saude Publica. 2010; 44:1039-45. | Article | PubMed

13. Hussain A, and Khanum A. Self-medication among university students of Islamabad, Pakistan- a preliminary study. Southern Med Review. 2008; 1:14-16. | Article

14. Chang FR and Trivedi PK. Economics of self-medication: theory and evidence. Health Econ. 2003; 12:721-39. I Article I PubMed

15. Worku S and Mariam A. Practise of Self-medication in Jimma Town. Ethiop J Health Dev. 2003; 17:111-116. I Pdf

16. Phalke VD, Phalke DB and Durgawale PM. Self-Medication Practises in Rural Maharashtra. Indian J Community Med. 2006; 31:34-35. I Article

17. Edwards DJ, Richman PB, Bradley K, Eskin B and Mandell M. Parental use and misuse of antibiotics: are there differences in urban vs. suburban settings? Acad Emerg Med. 2002; 9:22-6. I Article I PubMed

18. Olayemi SO, Akinyede AA and Oreagba Al. Prescription pattern at primary health care centres in Lagos State. Niger Postgrad Med J. 2006; 13:220-4. I Article I PubMed

19. Oshikoya KA. Evaluation of paediatric drug prescriptions in a teaching hospital in Nigeria for rational prescribing. Paed Perinat Drug Ther. 2006; 7:183-188.

20. Abasaeed A, Vlcek J, Abuelkhair M and Kubena A. Self-medication with antibiotics by the community of Abu Dhabi Emirate, United Arab Emirates. J Infect Dev Ctries. 2009; 3:491-7. I Article I PubMed

21. Sarahroodi S, Arzi A, Swalha AF and Ashtranezhad A. Antibiotic selfmedication among southern Iranian University Students. International J
Pharmacol. 2010; 6:48-52.

22. Nalini GK. Self-medication among allopathic medical Doctor in Karnataka India. British Journal of Med Prac. 2010; 3:325. I Article

23. Abasiubong F, Bassey EA, Udobang JA, Akinbami OS, Udoh SB and Idung $A U$. Self-Medication: potential risks and hazards among pregnant women in Uyo, Nigeria. Pan Afr Med J. 2012; 13:15. I Article I PubMed Abstract I PubMed Full Text

24. Salami KK. Household Social Reproductive Roles and Production of Child Health in Igbo-Ora Southwestern Nigeria. An unpublished Ph.D Thesis in the Department of Sociology, University of Ibadan, Ibadan, Nigeria. 2008.

25. Oshikoya KA, Senbanjo IO and Njokanma OF. Self-medication for infants with colic in Lagos, Nigeria. BMC Pediatr. 2009; 9:9. | Article | PubMed Abstract I PubMed Full Text

26. Goodman C, Brieger W, Unwin A, Mills A, Meek S and Greer G. Medicine sellers and malaria treatment in sub-Saharan Africa: what do they do and how can their practice be improved? Am J Trop Med Hyg. 2007; 77:203-18. | Article | PubMed Abstract | PubMed Full Text

27. Buabeng KO, Duwiejua M, Matowe LK, Smith F and Enlund H. Availability and choice of antimalarials at medicine outlets in Ghana: the question of access to effective medicines for malaria control. Clin Pharmacol Ther. 2008; 84:613-9. I Article I PubMed

28. Akuse RM, Eseigbe EE, Ahmed A and Brieger WR. Patent medicine sellers: how can they help control childhood malaria? Malar Res Treat. 2010; 2010:470754. | Article | PubMed Abstract | PubMed Full Text

29. Ehigiator O, Azodo CC, Ehizele AO, Ezeja EB and Ehigiator L et al. Selfmedication practices among dental, midwifery and nursing students. Eur J Gen Dentistry. 2013; 2:54-57| Article

30. Selley P. Self-prescribing by doctors. Health Trends. 1988; 20:128-9. | PubMed

31. Hem E, Stokke G, Tyssen R, Gronvold NT, Vaglum P and Ekeberg O. Selfprescribing among young Norwegian doctors: a nine-year follow-up study of a nationwide sample. BMC Med. 2005; 3:16. | Article | PubMed Abstract | PubMed Full Text

32. Agbaje EO and Uwakwe LO. Irrational use of antimicrobial agents in Surulere local government area of Lagos State, Nigeria. Niger Quart J Hosp Med. 2003; 13:68-71. I Article

33. National Population Commission (NPC, 2006) Report of final results of Census. 2006. I Website

34. Oyo State Independent Electoral Commission (OYSIEC) (n/a). Political wards in Ibadan North and Ibadan South-East Local Government Areas of Oyo State. 2013. I Website

35. Gureje O, Kola L, Afolabi E and Olley BO. Determinants of quality of life of elderly Nigerians: results from the Ibadan study of ageing. Afr J Med Med Sci. 2008; 37:239-47. | PubMed Abstract | PubMed Full Text

36. National Population Commission (NPC) (Nigeria) and ORC Macro. Demographic and Health Survey. 2008, Calverton, Maryland: National Population Commission and ORC Macro. 2009.

37. Adedire EB and Asekun-Olarinmoye EO. Caregivers home-care practises towards childhood febrile illness in urban and rural areas of Osun State Nigeria. Int'l Jour of Innovative Research and Studies. 2013; 2. I Article

38. Afolabi AO, Akinmoladun VI, Adebose IJ and Elekwachi G. Selfmedication profile of dental patients in Ondo State, Nigeria. Niger J Med. 2010; 19:96-103. I PubMed

39. Brieger WR, Osamor PE, Salami KK, Oladepo O and Otusanya SA. Interactions between patent medicine vendors and customers in urban and rural Nigeria. Health Policy Plan. 2004; 19:177-82. | Article | PubMed

40. Omolase CO, Adeleke OE, Afolabi AO and Afolabi OT. Self medication amongst general outpatients in a nigerian community hospital. Ann Ib Postgrad Med. 2007; 5:64-7. | Article I PubMed Abstract | PubMed Full Text

41. Upadhyay J and Joshi Y. Observation of drug utilization pattern and prevalence of disease in elderly patient through home medication review. Asian journal of pharmaceutical and clinical research. 2011; 4:144. | Pdf 
Salami et al. Research Journal of Drug Abuse 2015,

http://www.hoajonline.com/journals/pdf/2057-3111-2-2.pdf

42. Burak LJ and Damico A. College students' use of widely advertised medications. J Am Coll Health. 2000; 49:118-21. | Article | PubMed

43. Fawole OI and Onadeko MO. Knowledge and home management of malaria fever by mothers and care givers of under five children. West Afr J Med. 2001; 20:152-7. I PubMed

44. Sule SS. Childhood morbidity and treatment pattern at the multipurpose health centre, llesa, Nigeria. Niger J Med. 2003; 12:145-9. I PubMed

45. Adegboyega AA, Onayade AA and Salawu O. Care-seeking behaviour of caregivers for common childhood illnesses in Lagos Island Local Government Area, Nigeria. Niger J Med. 2005; 14:65-71. | PubMed

46. Ibeh CC, Ekejindu IM, Ibeh NC, Shu EN and Chukwuka JO. The pattern of home treatment of malaria in under-fives in south eastern Nigeria. Afr $\mathrm{J}$ Med Med Sci. 2005; 34:71-5. | Article | PubMed

\section{Citation:}

Salami KK and Adesanwo OJ. The practice of selfmedication for treatment of illnesses for under-five children by mothers in Ibadan, Nigeria. Res J Drug Abuse. 2015; 2:2.

http://dx.doi.org/10.7243/2057-3111-2-2 